\title{
Laccase Cathode Approaches to Physiological Conditions by Local pH Acidification
}

\author{
Sylvain Clot ${ }^{a}$, Cristina Gutierrez-Sanchez ${ }^{a}$, Sergey Shleev ${ }^{b}$, Antonio L. De Lacey ${ }^{* a}$, \\ Marcos Pita*a \\ $\mathrm{a}^{*}$ Instituto de Catalisis y Petroleoquimica, Consejo Superior de Investigaciones \\ Cientificas, C/ Marie Curie 2, 28049 Madrid, Spain. Fax: +34 915854760; Tel: \\ +34915854813; E-mail: marcospita@icp.csic.es \\ b Biomedical Laboratory Science and Technology, Faculty of Health and Society, \\ Malmo University, SE-205 06 Malmo, Sweden. Fax: +46406658100; Tel: \\ +46406657414; E-mail: sergey.shleev@mah.se
}

\begin{abstract}
A new conceptual approach to improve the performance of a laccase-based cathode at neutral $\mathrm{pH}$ is presented. The working $\mathrm{pH}$ of Trametes hirsuta laccase, typically acidic, can be achieved by oxidation of biological compounds such as glucose catalyzed by a second enzyme immobilized in the vicinity of the laccase electrode.
\end{abstract}

\section{Keywords}

Laccase, Biofuel Cell, Magnetic Nanoparticles, Local pH

\section{Introduction}

Biofuel cells using enzymes as catalysts are promising alternative sources of sustainable electric energy for the future.[1] One of the potential applications is to power implantable biomedical devices, using naturally existing biochemical substances (e.g. glucose in biofluids) as fuel.[2,3] The oxidation of the organic compound takes place at a bioanode[4] and the reduction of the oxygen takes place at a biocathode.[5] While the anode has been the subject of extensive research and development,[6] the performance of $\mathrm{O}_{2}$ reducing cathodes needs improvement.

Trametes hirsuta laccase (ThLc) is a polyphenol oxidase able to reduce $\mathrm{O}_{2}$ directly to $\mathrm{H}_{2} \mathrm{O}$ at high potential, i.e. close to $780 \mathrm{mV}$ vs. NHE.[7] Immobilization of Lc on electrodes has allowed measuring high current densities of $\mathrm{O}_{2}$ reduction at low overpotentials under optimum conditions of its enzymatic activity, overcoming the classic chloride inhibition limitation.[8,9] Besides chloride reversible inhibition, the main drawback when considering ThLc as an appropriate cathodic biocatalyst is its acidic $\mathrm{pH}$ optima (which ranges from 3 to 5), being almost completely inhibited at physiological pH. To overcome that limitation several approaches can be tested. Genetic manipulation of the enzyme for improving its activity close to neutral $\mathrm{pH}$ is a possibility, using either rational design or directed evolution, although it cannot be guaranteed that such a transformation will preserve its other catalytic properties.[10] Another approach takes advantage of the electrode surface size. For implantable biofuel cells the presence of miniaturized electrodes is desirable, so the creation of a local acidic environment in the vicinity of the 
electrode is feasible due to its small size. Local $\mathrm{pH}$ changes produced by enzymatic reactions have already proved to produce measurable changes on $\mathrm{pH}$-sensitive polyelectrolytes grafted to electrode surfaces.[11,12] If met with success, this approach could distinctively improve the performance of a ThLc-modified cathode under conditions where the bulk pH is several units above its activity range.

The present work seeks to identify a valid strategy for enhancing the ThLc performance under physiological conditions by generating a local acidic $\mathrm{pH}$ in the surroundings of the biocathode. An implantable biofuel cell should work as a fluidic system with a constant supply of glucose and $\mathrm{O}_{2}$ from the biological fluid. Anodic reactions will consume part of that glucose and oxidize it to gluconic acid, pKa 3.86. Usage of a multiple enzyme bioanode[4] would produce additional acidic compounds such as 2,3-diketogluconate, locally increasing the acidity. Placing the biocathode next to the bioanode output would produce an acidification of biocathode environment; improving its performance in the case of a Lc-modified electrode.

\section{Materials and Methods}

Enzymes. ThLc from the basidiomycete, strain T. hirsuta 56, was obtained from the laboratory collection of the Moscow State University of Engineering Ecology following the purification procedure previously reported.[13] Glucose oxidase (GOx) (Aspergillus Niger type II) and catalase (Bovine liver) were purchased from Sigma.

GOx modified magnetic nanoparticles. Amino-functionalized $\mathrm{CoFe}_{2} \mathrm{O}_{4}$ nanoparticles synthesis is detailed elsewere.[14] $1 \mathrm{mg}$ of GOx was placed into $250 \mu \mathrm{L} \mathrm{NaIO}_{4}, 10$ $\mathrm{mg} \cdot \mathrm{mL}^{-1}$, and let react $30 \mathrm{~min}$ and taken to $1 \mathrm{~mL}$ with $\mathrm{Na}_{2} \mathrm{HPO}_{4} .1 \mathrm{~mL}$ of $\mathrm{CoFe}_{2} \mathrm{O}_{4}$ $\mathrm{NH}_{2}$ nanoparticles, $10 \mathrm{mg} \cdot \mathrm{mL}^{-1}$ were added to the GOx-containing solution and left to react for $30 \mathrm{~min}$. Finally, GOx-magnetic nanoparticles were magnetically separated and redispersed twice with $100 \mu \mathrm{L}$ of $100 \mathrm{mM} \mathrm{Na}_{2} \mathrm{SO}_{4}$ solution.

Attachment of ThLc to graphite electrode. A Low-density graphite (LDG) was modified with ThLc according to a known procedure.[8]

Electrochemical measurements. All reagents were analytical grade and milli-Q water was used to prepare solutions. A $25 \mathrm{~mL}$ volume three-electrode electrochemical cell including an $\mathrm{Ag} / \mathrm{AgCl}$ reference electrode and a Pt wire as counter electrode was used. The working electrode was a gold wire for thionine monitorization socketed inside a NdFeB magnet ring together with the ThLc-LDG electrode. A solution containing the GOx-nanoparticles was deposited on the inner part of the magnetic ring. All DPV measurements ranged from $-0.3 \mathrm{~V}$ to $+0.2 \mathrm{~V}$, step potential $5 \mathrm{mV}$, Interval $0.01 \mathrm{~V}$. All CV measurements for $\mathrm{O}_{2}$ reduction ranged from $0.8 \mathrm{~V}$ to $0 \mathrm{~V}$ using $10 \mathrm{mV} \cdot \mathrm{s}^{-1} \mathrm{scan}$ rate. Chronoamperometry was measured under a $0.2 \mathrm{~V}$ bias potential.

Solutions. Thionine buffer, $\mathrm{pH}$ 7, contains $1 \mathrm{mM}$ thionine, $100 \mathrm{mM} \mathrm{Na}_{2} \mathrm{SO}_{4}$ and 1,500 units $\cdot \mathrm{mL}^{-1}$ of catalase. Acetate buffer, $\mathrm{pH} 4.2$, contains $10 \mathrm{mM}$ acetate, 100 $\mathrm{mM} \mathrm{NaClO}_{4}, 1 \mathrm{mM}$ thionine and 1,500 units $\cdot \mathrm{mL}^{-1}$ catalase. 
Thionine calibration. The cell was filled with a solution of $50 \mathrm{mM} \mathrm{Na}_{2} \mathrm{HPO}_{4}$ and 1 $\mathrm{mM}$ thionine. $\mathrm{pH}$ was adjusted with $\mathrm{HCl}$ to the values: 7.0, 6.5, 6.2, 5.7, 5.1, 4.9, 4.3, and 3.7.

\section{Results and discussion}

The cathodic performance of a ThLc-LDG modified electrode at bulk pH 7 was studied in presence of GOx-magnetic nanoparticles concentrated close to the electrode [Scheme 1]. $\mathrm{pH}$ changes produced by $1 \mathrm{~mL}$ of $\mathrm{CoFe}_{2} \mathrm{O}_{4}-\mathrm{NH}_{2}-\mathrm{GOx} 1$ $\mathrm{mg} \cdot \mathrm{mL}^{-1}$ were compared to those produced by GOx $0.1 \mathrm{mg} \cdot \mathrm{mL}^{-1}$ in $1 \mathrm{~mL}$ solution of $\mathrm{Na}_{2} \mathrm{SO}_{4} 100 \mathrm{mM}$ [Figure $1 \mathrm{~A}$ ], showing that both free GOx and immobilized GOx are able to produce a $\mathrm{pH}$ change bigger than 1.5 units in less than $30 \mathrm{~min}$.

Thionine was included in the system for two purposes. Firstly, to act as $\mathrm{pH}$ dependent electrochemical probe and monitor the local $\mathrm{pH}$ around the electrode surface via DPV. 15 Thionine response was measured on an independent gold wire placed near to the ThLc-LDG electrode to avoid possible interferences between the electrocatalytical $\mathrm{O}_{2}$ reduction and the thionine redox process, even though its activity range is $500 \mathrm{mV}$ lower than laccase activity. The second purpose of thionine addition was to serve as weak buffer at $\mathrm{pH}$ above 6.[15]

Prior to the electrocatalytic experiments, the thionine electrochemical response dependence on $\mathrm{pH}$ was calibrated. Figure 1B shows the DPV results for each $\mathrm{pH}$ value and the fitting of the peak values to two straight lines, one for the values above pH 6 [equation (1)] and another for the values below [equation (2)]. This behaviour is related to the buffering properties of thionine, as its deprotonation occurs at $\mathrm{pH}$ above 6.[15]

$$
\begin{aligned}
& \mathrm{pH} \geq 6 \mathrm{E}(\mathrm{DPV} \text { peak })=0.066 \cdot \mathrm{pH}+0.29 \\
& \mathrm{pH} \leq 6 \mathrm{E}(\mathrm{DPV} \text { peak })=0.030 \cdot \mathrm{pH}+0.08
\end{aligned}
$$

The electrocatalytic measurements were performed with the working electrode shown in Scheme 1. Glucose $50 \mathrm{mM}$ was added to the solution, triggering the production of gluconic acid. During $2 \mathrm{~h}$ several measurements were recorded on the running experiment: CVs at the ThLc-LDG electrode for measuring the electrocatalytic reduction of $\mathrm{O}_{2}$ evolution [Figure 2A] and DPVs at the gold wire for monitoring the local $\mathrm{pH}$ evolution from the $\mathrm{E}_{\max }$ of thionine [Figure 2B]. The resulting increase of laccase electroactivity with time is clear when compared to the response given by the same electrode placed in acetate buffer after $90 \mathrm{~min}$ in glucose $50 \mathrm{mM}$ [Figure 2A, line (i)]. Gluconic acid diffusion to the bulk was monitored with a $\mathrm{pH}$-meter and compared with the local $\mathrm{pH}$ around the working electrode measured by DPV of thionine [Figure 2B]. Once the experiment was concluded the solution was homogenised and both bulk and local $\mathrm{pH}$ were measured to check their convergence [Figure 2B]. The results show that after $2 \mathrm{~h}$ the environment of the working electrode was acidified ca. 100 -fold ( $2 \mathrm{pH}$ units) relative to the bulk, which allowed the ThLc to increase its $\mathrm{O}_{2}$ reduction rate. It should be noted that both GOx and Lc compete for $\mathrm{O}_{2}$, which has to diffuse to the electrode surface.[16] This obstacle was addressed by adding catalase, which turns the $\mathrm{H}_{2} \mathrm{O}_{2}$ produced by GOx to $\mathrm{O}_{2}$, increasing the effective $\mathrm{O}_{2}$ available for the oxidases. 
The Lc-modified electrode performance for $\mathrm{O}_{2}$ reduction was measured by chronoamperometry under (a) thionine buffer, and (b) acetate buffer. In both cases the bulk $\mathrm{pH}$ was monitored with a pH-meter. After stabilization of the current $50 \mathrm{mM}$ glucose was added to the system. In case (a) a bulk pH of 6.8 was measured just before the glucose addition. Once the glucose was added the current gradually evolved to more negative values (ca. 3-fold after $130 \mathrm{~min}$ ), which indicates that the immobilized ThLc was increasing its activity of $\mathrm{O}_{2}$ reduction [Figure 3a]. The local $\mathrm{pH}$ at the end of the experiment was 5 while the bulk pH was 6.5. In case (b) the current trend continued in the same direction after glucose addition. A slight decrease in the current was produced at the moment of addition, which can be attributed to a small depletion of $\mathrm{O}_{2}$ due to the onset of GOx activity not fully compensated by catalase [Figure $3 \mathrm{~b}$ ]. The bulk $\mathrm{pH}$ remained constant along the entire experiment under acetate buffer.

\section{Conclusions}

We have shown a conceptual approach for addressing a major problem when using Lc as cathodic biocatalysts in potentially implantable biofuel cells. ThLc-graphite cathode performed a better $\mathrm{O}_{2}$ reduction when locally acidic conditions were facilitated, sidetracking a mild $\mathrm{pH} 7$ buffer.

Miniaturization of the Lc-cathode could facilitate a system able to create a local acidic environment under stronger buffers, similar to biofluids. This could be achieved by the appropriate combination of the Lc-cathode with a multiple saccharide-oxidizing bioanode,[4] which will produce acidic compounds that will flow to the cathode.

Future work will aim at miniaturizing the Lc electrode and combining it with a multiple oxidase anode in an implantable biofuel cell prototype.

\section{Acknowledgements}

This work was funded by the FP7 project "3D-Nanobiodevice" (NMP4-SL-2009229255) and by the Spanish MICINN project (CTQ2009-12649). M.P. acknowledges the Ramon y Cajal 2009 program from the Spanish MICINN.

\section{References}

[1] F. Davis, S. P. J. Higson, Biosensors \& Bioelectronics 22 (2007) 1224.

[2] S. C. Barton, J. Gallaway, P. Atanassov, Chemical Reviews 104 (2004) 4867.

[3] A. Heller, Analytical and Bioanalytical Chemistry 385 (2006) 469.

[4] F. Tasca, L. Gorton, M. Kujawa, I. Patel, W. Harreither, C. K. Peterbauer, R. Ludwig, G. Noll, Biosensors \& Bioelectronics 25 (2010) 1710.

[5] S. C. Barton, H. H. Kim, G. Binyamin, Y. Zhang, A. Heller, Journal of the American Chemical Society 123 (2001) 5802.

[6] N. Mano, F. Mao, A. Heller, Journal of Electroanalytical Chemistry 574 (2005) 347. 
[7] S. Shleev, A. Christenson, V. Serezhenkov, D. Burbaev, A. Yaropolov, L. Gorton, T. Ruzgas, Biochemical Journal 385 (2005) 745.

[8] C. Vaz-Dominguez, S. Campuzano, O. Rudiger, M. Pita, M. Gorbacheva, S. Shleev, V. M. Fernandez, A. L. De Lacey, Biosensors \& Bioelectronics 24 (2008) 531.

[9]M. Pita, C. Gutierrez-Sanchez, D. Olea, M. Velez, C. Garcia-Diego, S. Shleev, V. M. Fernandez, A. L. De Lacey, Journal of Physical Chemistry C 115 (2011) 13420.

[10] D. Maté, C. García-Burgos, E. García-Ruíz, A. Ballesteros, S. Camarero, M. Alcalde, Chemistry \& Biology 17 (2010) 1030.

[11] M. Pita, T. K. Tam, S. Minko, E. Katz. ACS Applied Materials \& Interfaces 1 (2009) 1166.

[12] V. Bocharova, T. K. Tam, J. Halamek, M. Pita, E. Katz, Chemical Communications 46 (2010) 2088.

[13] Shleev, S.; Morozova, O. V.; Nikitina, V. O.; Gorshina, E. S.; Rusinova, T. V.; Serezhenkov, V. A.; Burbaev, D. S.; Gazaryan, I. G.; Yaropolov, A. I. Biochimie 86 (2004) 693.

[14] M. Pita, J. M. Abad, C. Vaz-Dominguez, C. Briones, E. Mateo-Marti, J. A. MartinGago, M. P. Morales, V. M. Fernandez, Journal of Colloid \& Interface Science 321 (2008) 484.

[15] A. Salimi, N. Amini, H. Danyali, R. Hallaj, Electroanalysis 18 (2006) 1664.

[16] S. Cosnier, C. Mousty, A. Guerloget, M. S. P. Lopez, D. Shan, Electroanalysis, 23 (2011) 1776. 


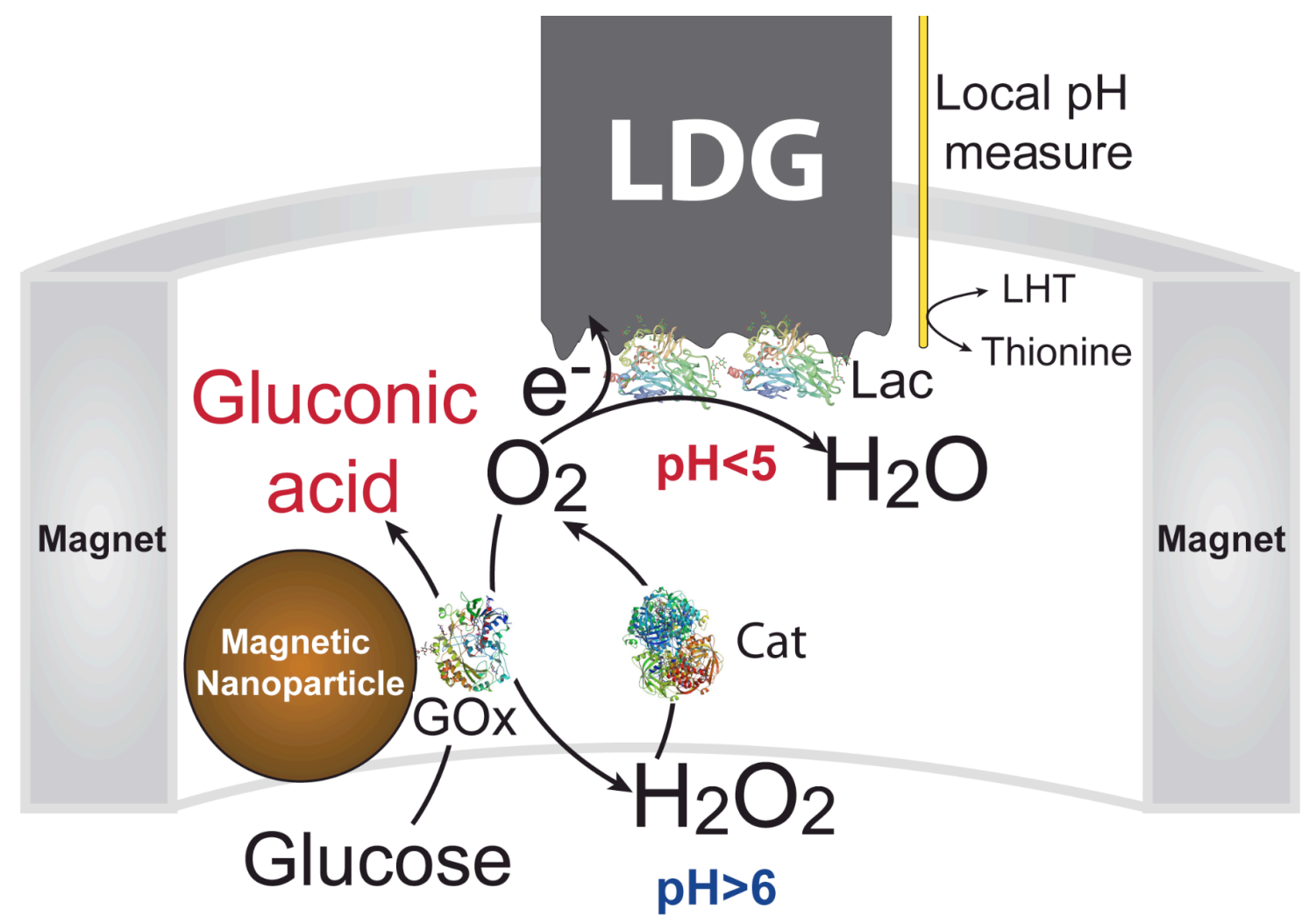

Scheme 1. Electroenzymatic system for creating an acidic local $\mathrm{pH}$ in the surrounding of a ThLc modified graphite electrode. 

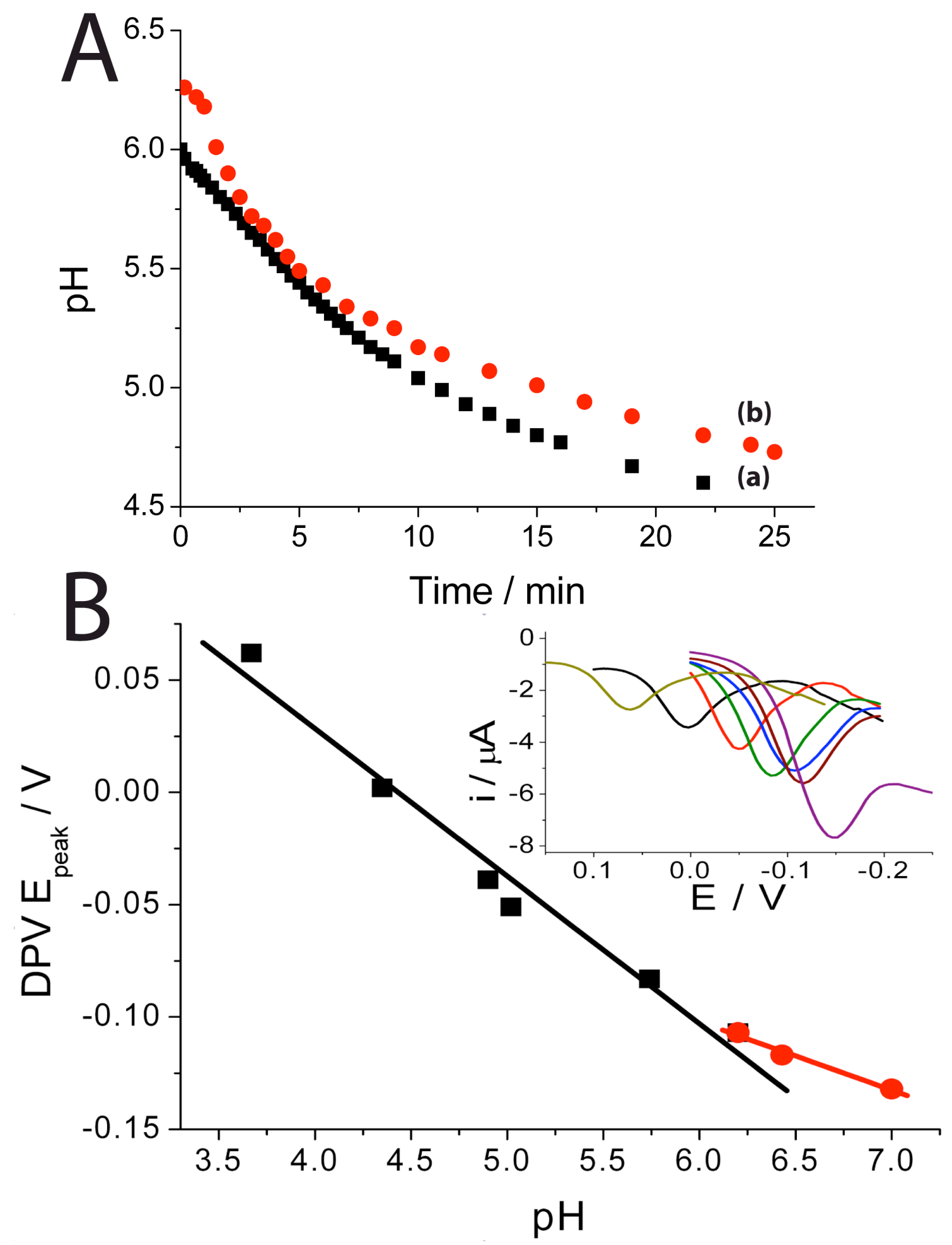

Figure 1. (A) Evolution of $\mathrm{pH}$ caused by gluconic acid produced by (a) GOx in solution and (b) GOx attached to magnetic nanoparticles. (B) Peak values of DPVThionine response at different $\mathrm{pH}$ values and fit to two different straight lines. ${ }^{15}$ Inset: Thionine DPV response at different $\mathrm{pH}$ values. 

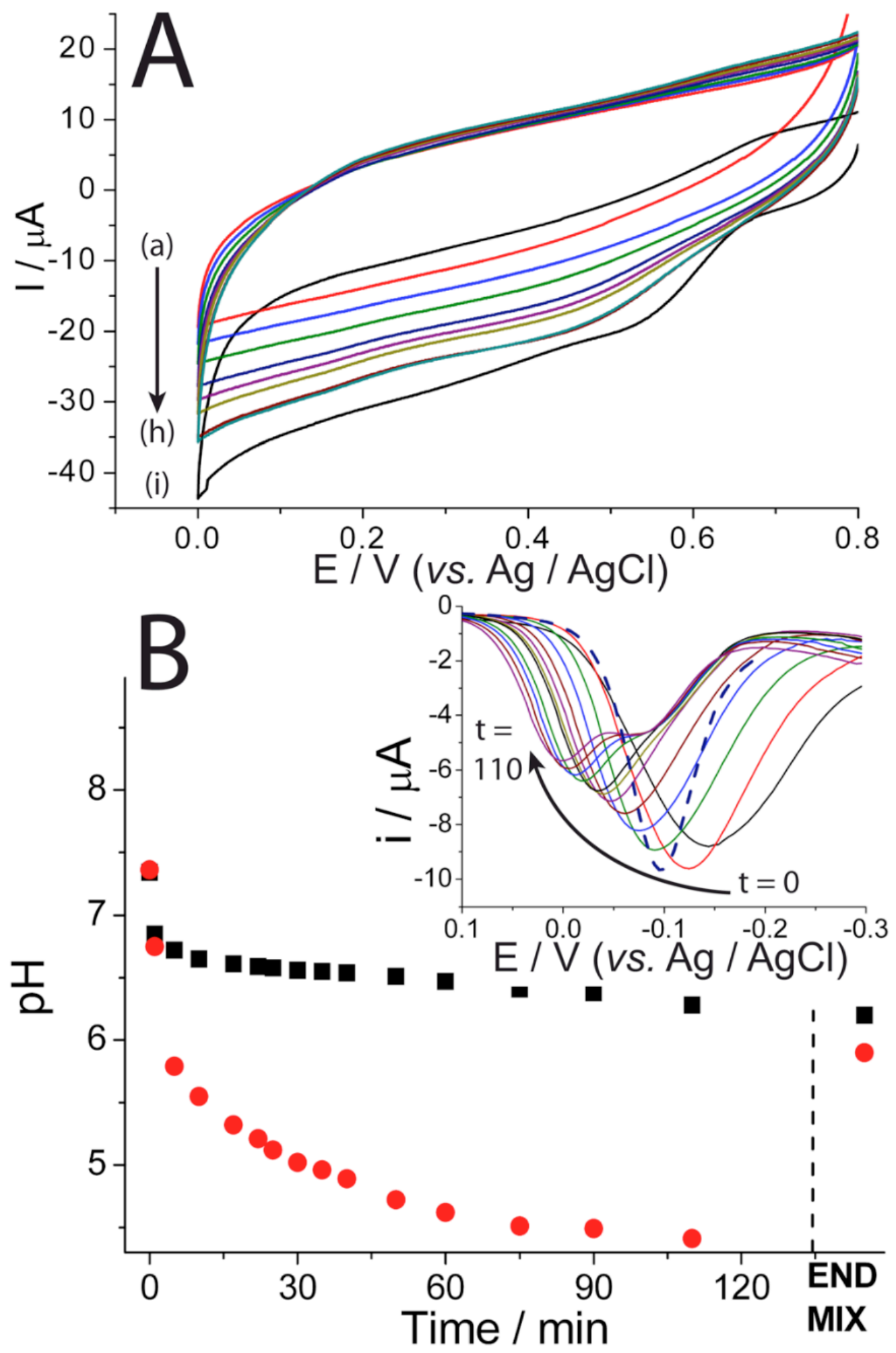

Figure 2. (A) Cyclic voltammograms of laccase electroactivity recorded in presence of thionine, glucose and catalase at time (a) 0, (b) 10, (c) 30, (d) 45, (e) 60, (f) 75, (g) 100 and (h) 120 minutes; (i) Reference activity at 10 mM acetate / $100 \mathrm{mM}$ perchlorate $\mathrm{pH} 4.2$ buffer solution. (B) Local (red circle) and bulk (black square) evolution of pH during the experiment. Final "End mix" corresponds to homogenization of the solution. Inset: DPV evolution during time; dashed line corresponds to "End mix" DPV response. All the measurements were airequilibrated. 


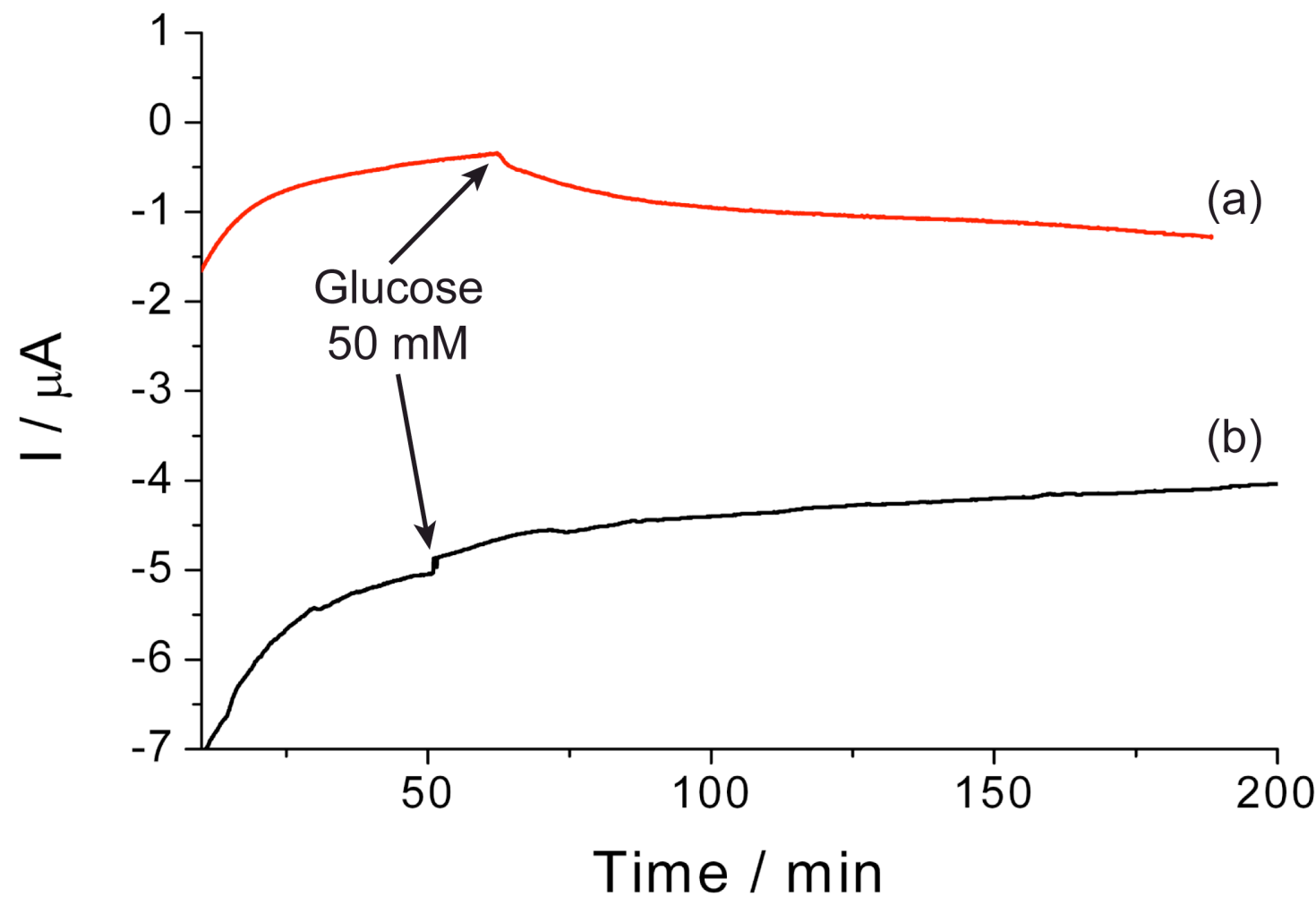

Figure 3. Chronoamperometry signal recorded at $+200 \mathrm{mV}$ in (a) $1 \mathrm{mM}$ thionine $\mathrm{pH} 6.8$ solution and (b) $10 \mathrm{mM}$ acetate $\mathrm{pH} 4.2$. Addition of glucose $50 \mathrm{mM}$ is shown for both experiments. 